\title{
PENAMBAHAN JAMBU BIJI MERAH TERHADAP MUTU ORGANOLEPTIK MIE BEKATUL UNTUK ANAK OBESITAS
}

\author{
Addition Of Red Seed Mushrooms To The Quality Of Organoleptic Mixed Mies For Obesity \\ Children \\ Mujahidah Fidienia Harliani ${ }^{1}$, Maryam Razak ${ }^{1}$ \\ ${ }^{1}$ Jurusan Gizi Politeknik Kesehatan Kemenkes Malang \\ Email : maryamrazak0811@gmail.com
}

\begin{abstract}
ABSTRAK
Prevalensi obesitas semakin meningkat dari tahun ke tahun terutama pada anak sekolah yang disebabkan oleh rendahnya konsumsi serat per orang di Indonesia. Salah satu upaya penanggulangan obesitas adalah melakukan penambahan jambu biji merah pada mie basah yang telah disubstitusi dengan tepung bekatul. Pengembangan produk dengan penambahan jambu biji merah pada mie basah bekatul sebagai pangan fungsional tinggi serat yang diharapkan dapat menjadi alternatif pilihan makanan bagi penderita obesitas khususnya pada anak usia 7-9 tahun. Mie basah menjadi pilihan alternatif karena mudahnya pengolahan mie basah yang telah dikenal masyarakat. Tujuan penelitian adalah menganalisis mutu organoleptik (warna, aroma, rasa dan tekstur) pada mie basah tepung bekatul dengan penambahan jambu biji merah untuk anak sekolah yang obesitas. Jenis penelitian eksperimental laboratorium dengan menggunakan desain penelitian Rancangan Acak Lengkap (RAL). Taraf perlakuan adalah perbandingan tepung terigu: tepung bekatul dan jambu biji merah yaitu $\mathrm{P}_{0}=(90: 10: 0), \mathrm{P}_{1}=(90: 10: 25), \mathrm{P}_{2}=(90: 10: 30), \mathrm{P}_{3}=(90: 10: 35)$. Hasil penelitian menunjukkan bahwa mutu organoleptik warna, aroma, rasa, dan tekstur berpengaruh signifikan terhadap penambahan jambu biji merah pada mie basah bekatul. Taraf perlakuan $\mathrm{P}_{1}$ merupakan taraf perlakuan terbaik. Mie basah bekatul dengan penambahan jambu biji merah untuk perlakuan terbaik dapat dijadikan sebagai makanan alternatif untuk penurunan berat badan karena merupakan produk tinggi serat dengan kadar serat 4,18 g/100 g. Saran untuk penelitian ini adalah perlu penambahan BTP untuk memperbaiki tekstur mie basah agar lebih kenyal dan tidak mudah putus, yaitu STPP (sodium tri polyphospat). Selain itu tekstur mie terasa berpasir sehingga sebaiknya biji jambu merah tidak digunakan.

Kata kunci : Anak obesitas, Mie Basah bekatul, jambu biji merah, mutu organoleptik
\end{abstract}

\section{ABSTRACT}

The prevalence of obesity is increasing year by year, especially in school children due to low fiber consumption per person in Indonesia. One effort to overcome obesity is to add red guava to wet noodles that have been substituted with bran flour. Product development with the addition of red guava on rice bran wet noodles as high-fiber functional food which is expected to be an alternative food choice for obese sufferers especially in children aged 7-9 years. Wet noodles are an alternative choice because of the ease of processing wet 
noodles that have been known to the public. The aim of the study was to analyze organoleptic quality (color, aroma, taste and texture) in wet rice bran flour noodles with the addition of red guava for obese school children. Type of laboratory experimental research using a completely randomized design (CRD) research design. The treatment level is the ratio of wheat flour: bran flour and red guava which is $P 0=(90: 10: 0), P 1=$ (90:10:25), $P 2=(90: 10: 30), P 3=(90: 10: 35)$. The results showed that the organoleptic quality of color, aroma, taste, and texture had a significant effect on the addition of red guava to bran wet noodles. Treatment level P1 is the best treatment level. Bran wet noodles with the addition of red guava for the best treatment can be used as an alternative food for weight loss because it is a high fiber product with fiber content of $4.18 \mathrm{~g} / 100 \mathrm{~g}$. Suggestions for this research are the need to add BTP to improve the texture of wet noodles to make them more chewy and not easily broken, namely STPP (sodium tri polyphosphate). In addition, the texture of the noodles feels sandy, so you should not use red guava seeds.

Keywords: Obese children, Mie Basah bekatul, red guava, organoleptic quality

\section{PENDAHULUAN}

Secara nasional masalah gemuk pada anak umur 5-12 tahun masih tinggi yaitu $18,8 \%$, terdiri dari gemuk $10,8 \%$ dan sangat gemuk (obesitas) $8,8 \%$. Prevalensi gemuk terendah di Nusa Tenggara Timur $(8,7 \%)$ dan tertinggi di DKI Jakarta $(30,1 \%)$. Sebanyak 15 provinsi dengan prevalensi sangat gemuk diatas nasional, yaitu Kalimantan Tengah, Jawa Timur, Banten, Kalimantan Timur, Bali, Kalimantan Barat, Sumatera Utara, Kepulauan Riau, Jambi, Papua, Bengkulu, Bangka Belitung, Lampung dan DKI Jakarta (Riskesdas, 2013). Makanan dengan kandungan serat kasar yang tinggi dapat menurunkan berat badan. Makanan akan tinggal dalam saluran pencernaan dalam waktu yang relatif singkat sehingga absorbsi zat makanan akan berkurang, selain itu makanan yang mengandung serat relatif tinggi akan memberi rasa kenyang sehingga menurunkan konsumsi makanan, karena makanan yang berserat tinggi biasanya mengandung kalori rendah, kadar gula dan lemak rendah yang dapat membantu mengurangi terjadinya obesitas (Anonim, 2006).

Salah satu limbah yang dapat dimanfaatkan adalah bekatul. Bekatul adalah kulit beras merah ataupun putih yang lepas dari bagian beras karena proses penggilingan atau penumbukan. Berdasarkan penelitian Fitriyaningsih, dkk (2011) tentang pemanfaatan tepung bekatul terhadap daya terima mie basah bahwa 
hanya $10 \%$ substitusi tepung bekatul yang dapat diterima oleh panelis dari segi warna, rasa, aroma dan tekstur mie basah. Substitusi bekatul sebanyak 10\% hanya didapatkan kandungan serat sebesar 1,31 gram serat/100 gram. Kandungan serat ini masih sangat kurang dari kebutuhan serat anak usia 7-9 tahun yaitu 5,2-7,8 gram, sehingga perlu ditambahkan bahan pangan lain yang memiliki kadar serat tinggi untuk meningkatkan kandungan serat dari mie basah.

Pemanfaatan bahan makanan lokal berupa sayur dan buah sangat membantu mencegah kenaikan berat badan pada penderita obesitas, karena sayur dan buah mengandung kadar serat, baik kadar serat halus maupun serat kasar. Jambu biji merah memiliki kandungan serat lebih tinggi apabila dibandingkan dengan buah apel, yaitu sebesar 22,5 gram serat/100 gram (Depkes, 2005). Oleh sebab itu, dilakukan pengembangan produk dengan penambahan jambu biji merah pada produk mie basah bekatul sebagai pangan fungsional tinggi serat yang diharapkan dapat menjadi alternatif pilihan makanan bagi penderita obesitas khususnya anak usia 7-9 tahun.

\section{METODELOGI PENELITIAN Jenis dan Desain Penelitian}

Penelitian ini mengggunakan jenis penelitian eksperimen dengan desain penelitian Rancangan Acak Lengkap (RAL) menggunakan 4 taraf perlakuan dengan 3 kali replikasi yaitu berdasarkan campuran tepung bekatul (tepung terigu 90\% dan tepung bekatul 10\%) dengan jambu biji merah yang terdiri dari 4 level $(0 \%, 25 \%$, $30 \%$ dan $35 \%)$, yaitu $\mathrm{P}_{0}=(90: 10: 0)$, $\mathrm{P}_{1}=(90: 10: 25)$,

$$
\mathrm{P}_{2}=(90: 10: 30) \text {, }
$$

$\mathrm{P}_{3}=(90: 10: 35)$. Dasar penentuan taraf proporsi penambahan jambu biji merah didasarkan pada kebutuhan rata-rata serat anak usia 7-9 tahun per hari anak Indonesia sesuai dengan Angka Kecukupan Gizi (AKG) 2013, yaitu 26 gram/hari. Proporsi makanan utama dalam satu porsi yaitu 20\%-30\%, sehingga rentang kebutuhan serat adalah 5,2-7,8 gram serat/100 gram. Penambahan jambu biji merah sebanyak 25\%-35\% dapat memenuhi kebutuhan serat anak yaitu 4,85-6,28 gram serat/100 gram. Sebanyak 20 orang panelis yang digunakan untuk uji organoleptik mie basah dengan penambahan jambu biji merah merupakan replikasi taraf perlakuan, sedangkan analisis kandungan gizi dan daya putus serta 
elastisitas hanya dilakukan pada perlakuan terbaik.

\section{Bahan dan Alat}

\section{Bahan}

Bahan yang ditambahkan dalam penelitian ini adalah jambu biji merah. Jumlah bahan masing-masing taraf perlakuan dan total bahan penyusun mie basah yang dibutuhkan disajikan pada Tabel 1 dan Tabel 2. Bahan yang digunakan untuk analisis kimia dan mutu fisik pada perlakuan terbaik yaitu: kadar protein (mie basah bekatul, tablet kjedhal, aquades, $\mathrm{H}_{2} \mathrm{SO}_{4}$, indicator pp, $\mathrm{NaOH}$-thio $60 \%$, asam borat $4 \%$ yang diberi indikator MRBCG, $\mathrm{HCl}$ 0,002 N; kadar lemak (mie basah bekatul, chloroform, kertas saring); kadar serat kasar (mie basah bekatul, alkohol 95\%); kadar air, kadar abu, dan daya putus (mie basah bekatul).

\section{Alat}

Alat yang digunakan dalam penelitian ini adalah: 1) pengolahan mie basah adalah gelas ukur, timbangan bahan makanan, sendok makan, baskom besar, panci, kompor, penggiling mie, piring, 2) pengolahan tepung bekatul adalah baskom, blender tepung, ayakan, dan sendok makan,
3) pengolahan jambu biji merah adalah pisau, talenan, gelas ukur, dan juicer, 4) Alat yang digunakan untuk analisis kimia antara lain timbangan analitik, tabung kjeldhal, spatula, pipet ukur $5 \mathrm{ml}$, pipet ukur $10 \mathrm{ml}$, pipet tetes, hot plate, labu ukur, beaker glass, tabung destilasi, erlenmeyer, labu destilasi, desikator, oven, soxhlet, cawan porselen, penjepit cawan, pembakar bunsen, tanur, gelas arloji, mortal dan pastel, dan pendingin balik (kondensor), 5) Daya putus dan elastisitas menggunakan alat Tensile Strength Instrument.

\section{Tahap Penelitian}

Penelitian dilaksanakan dalam dua tahap yaitu:

\section{Penelitian Pendahuluan}

Penelitian pendahuluan dilakukan dengan tujuan untuk mencari formulasi atau kombinasi nilai energi dan kadar serat optimal pada mie basah bekatul dengan penambahan jambu biji merah. Konsentrasi penambahan jambu biji merah yang digunakan adalah 0\% untuk kontrol (P0), $25 \%$ untuk perlakuan 1 (P1), 30\% untuk perlakuan $2(\mathrm{P} 2)$, dan $35 \%$ untuk perlakuan 3 (P3).

\section{Penelitian Utama}


Penelitan utama dilakukan Whitney. Analisis nilai energi, mutu kimia pengolahan mie basah bekatul dan analisis (karbohidrat, protein, lemak dan serat mutu organoleptik, yaitu analisis statistik kasar) dan mutu fisik (daya putus dan Kruskall Wallis pada tingkat kepercayaan elastisitas) dilakukan pada taraf perlakuan 95\% dan uji Post Hoc (uji lanjut) Mann terbaik.

Tabel 1. Kebutuhan Bahan Tiap Perlakuan dalam Pengolahan Mie Basah Bekatul

\begin{tabular}{|l|c|c|c|c|c|}
\hline \multirow{2}{*}{ Bahan } & \multirow{2}{*}{ Satuan } & \multicolumn{4}{c|}{$\sum$ Bahan Masing-Masing Taraf Perlakuan } \\
\cline { 3 - 6 } & & $\mathrm{P}_{0}$ & $\mathrm{P}_{1}$ & $\mathrm{P}_{2}$ & $\mathrm{P}_{3}$ \\
\hline $\begin{array}{l}\text { Tepung terigu protein } \\
\text { tinggi }\end{array}$ & Gram & 351 & 351 & 351 & 351 \\
\hline Tepung bekatul & Gram & 39 & 39 & 39 & 39 \\
\hline Tepung tapioka & Gram & 25 & 25 & 25 & 25 \\
\hline Jambu biji merah & Gram & - & 97,5 & 117 & 136,5 \\
\hline Kuning Telur & Butir & 3 & 3 & 3 & 3 \\
\hline Garam & Sdm & 8 & 8 & 8 & 8 \\
\hline Minyak & Sdm & $1 \frac{11}{2}$ & $11 / 2$ & $11 / 2$ & $11 / 2$ \\
\hline Air & $\mathrm{ml}$ & 153 & 153 & 153 & 153 \\
\hline
\end{tabular}

Tabel 2. Total Kebutuhab Bahan Baku Mie Basah Bekatul yang dibutuhkan

\begin{tabular}{|l|c|c|c|c|c|c|}
\hline \multirow{2}{*}{ Bahan } & \multirow{2}{*}{ Satuan } & \multicolumn{4}{c|}{$\begin{array}{c}\text { B Bahan Masing-Masing Taraf } \\
\text { Perlakuan dan Replikasi }\end{array}$} & \multirow{2}{*}{$\begin{array}{c}\text { Total } \\
\text { Bahan }\end{array}$} \\
\cline { 3 - 6 } & & P0 & P1 & P2 & P3 & \\
\hline $\begin{array}{l}\text { Tepung terigu protein } \\
\text { tinggi }\end{array}$ & Gram & 1053 & 1053 & 1053 & 1053 & 4212 \\
\hline Tepung bekatul & Gram & 117 & 117 & 117 & 117 & 468 \\
\hline Tepung tapioka & Gram & 75 & 75 & 75 & 75 & 300 \\
\hline Jambu biji merah & Gram & - & 292,5 & 351 & 409,5 & 1053 \\
\hline Telur & Butir & 9 & 9 & 9 & 9 & 36 \\
\hline Garam & Gram & 24 & 24 & 24 & 24 & 96 \\
\hline Minyak & Sdm & $41 / 2$ & $41 / 2$ & $41 / 2$ & $41 / 2$ & 18 \\
\hline Air & ml & 459 & 459 & 459 & 459 & 1836 \\
\hline
\end{tabular}

Prosedur Pengolahan Mie Basah Bekatul Pengolahan Bekatul

Bekatul yang sudah dipilih sesuai dengan standar mutu bekatul, sebelum diolah menjadi mie basah diayak terlebih dahulu untuk mendapatkan bekatul yang halus, kemudian disangrai selama 7 menit di atas api kecil. Penyangraian ini bertujuan untuk menghilangkan bau langu pada bekatul. Setelah disangrai, bekatul diayak kembali untuk mendapatkan tepung bekatul yang lebih halus. Tepung bekatul siap 
digunakan untuk disubstitusi dengan tepung terigu.

\section{Pengolahan Jambu Biji Merah}

Jambu biji merah yang digunakan masih dalam keadaan segar dan mengkal. Kemudian jambu biji dicuci bersih dengan air mengalir. Setelah itu, dipotong-potong dan memisahkan daging buah dan bijinya. Menghaluskan daging buah dengan menggunakan juicer, menghaluskan biji jambu biji merah menggunakan waring blender, kemudian campur dengan daging buah yang telah halus.

\section{Penimbangan Bahan}

(tepung terigu, tepung bekatul, tepung tapioka dan sari jambu biji merah untuk perlakuan $\mathrm{P} 1, \mathrm{P} 2$, dan P3)

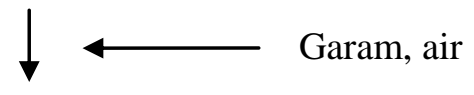

Pencampuran bahan

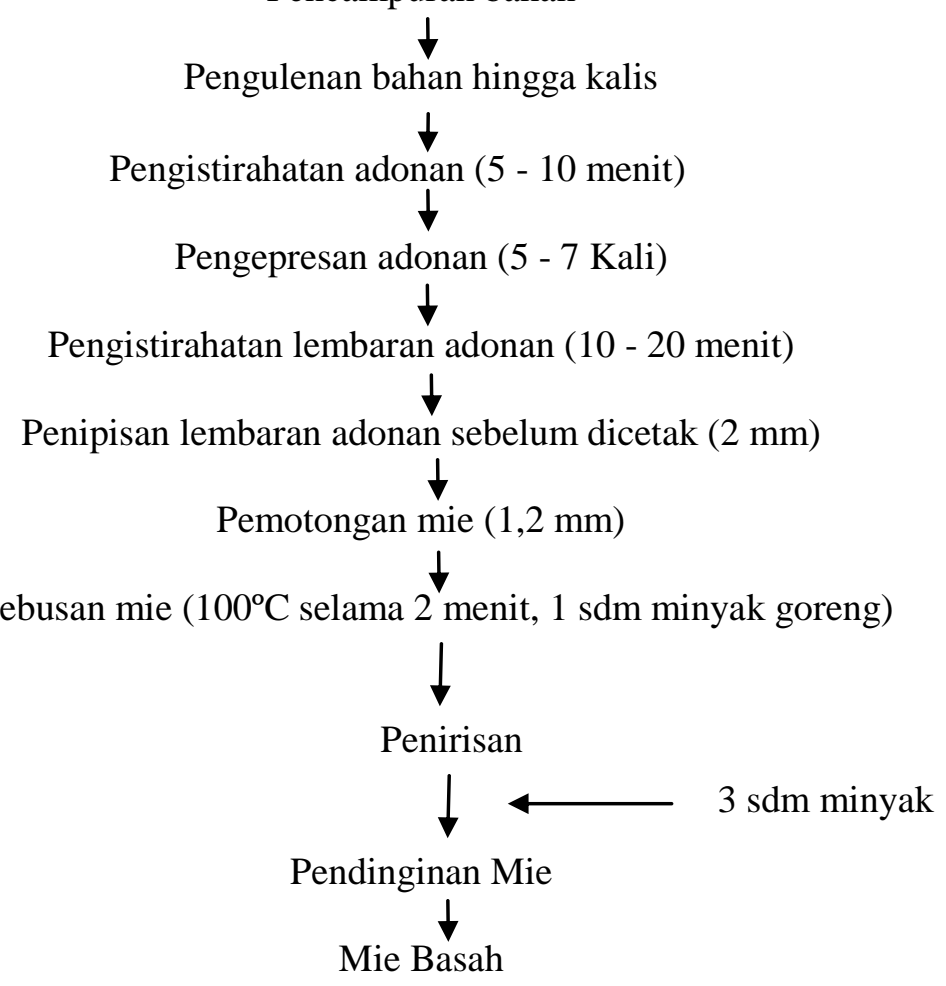

Gambar 1. Diagram Alir Pembuatan Mie Basah (Rustandi, 2011) 


\section{HASIL DAN PEMBAHASAN}

\section{Mutu Organoleptik}

Hasil uji organoleptik mie basah dengan penambahan jambu biji merah dilakukan untuk mendapatkan tanggapan panelis terhadap warna, aroma, rasa dan tekstur mie basah bekatul.

\section{Warna}

Tingkat kesukaan panelis terhadap warna mie basah dari taraf perlakuan $\mathrm{P}_{0}$ sampai $\mathrm{P}_{3}$ semakin meningkat. Hal ini cenderung dipengaruhi oleh penambahan jambu biji merah. Tingkat Kesukaan Panelis terhadap Warna Mie Basah bekatul disajikan pada Tabel 3.

Tabel 3. Tingkat Kesukaan Panelis terhadap Warna Mie Basah

\begin{tabular}{|c|c|c|c|c|c|}
\hline $\begin{array}{c}\text { Taraf Perlakuan } \\
\text { (Tepung Terigu : }\end{array}$ & \multicolumn{3}{|c|}{ Jumlah Panelis } & \multirow{2}{*}{ Modus } \\
\cline { 2 - 6 } $\begin{array}{c}\text { Tepung Bekatul : } \\
\text { Jambu Biji Merah) }\end{array}$ & $\begin{array}{c}\text { Sangat Tidak } \\
\text { Suka }\end{array}$ & Tidak Suka & Suka & $\begin{array}{c}\text { Sangat } \\
\text { Suka }\end{array}$ & \\
\hline $\mathrm{P}_{0}(90: 10: 0)$ & 4 & 7 & 5 & 4 & $2^{\mathrm{a}}$ \\
\hline $\mathrm{P}_{1}(90: 10: 25)$ & 0 & 7 & 10 & 3 & $3^{\mathrm{a}}$ \\
\hline $\mathrm{P}_{2}(90: 10: 30)$ & 0 & 5 & 13 & 2 & $3^{\text {ab }}$ \\
\hline $\mathrm{P}_{3}(90: 10: 35)$ & 0 & 2 & 11 & 7 & $3^{\mathrm{c}}$ \\
\hline
\end{tabular}

Keterangan : Huruf yang berbeda menunjukkan adanya perbedaan yang signifikan $(\alpha=0,05)$

Warna pada taraf perlakuan $\mathrm{P}_{0}$ cenderung pucat dan peningkatan proporsi jambu biji merah menghasilkan warna merah muda pada mie basah $\left(\mathrm{P}_{1}, \mathrm{P}_{2}, \mathrm{P}_{3}\right)$. Warna merah muda ini berasal dari pigmen jambu biji, dimana ditemukan likopen yaitu zat karotenoid (Parimin,2007). Berdasarkan hasil analisis statistik Kruskal Wallis menunjukkan bahwa penambahan jambu biji merah memberikan pengaruh yang signifikan $(\mathrm{p}=0,029)$ terhadap warna mie basah. Selanjutnya dilakukan Uji lanjut Man-Whitney untuk mengetahui pasangan mana yang berbeda. Perlakuan yang memberikan pengaruh signifikan terhadap warna mie basah adalah $\mathrm{P}_{0}$ dengan $\mathrm{P}_{3}$ dan $\mathrm{P}_{2}$ dengan $\mathrm{P}_{3}$. Taraf perlakuan $\mathrm{P}_{3}$ cenderung disukai oleh panelis. Menurut Winarno (2008) menyatakan bahwa ada lima hal yang menyebabkan suatu bahan makanan berwarna, salah satunya adalah pigmen yang berasal dari hewan atau tumbuhan.

\section{Aroma}

Tingkat kesukaan panelis terhadap aroma mie basah bekatul disajikan pada Tabel 4 . 
Tabel 4. Tingkat Kesukaan Panelis terhadap Aroma Mie Basah

\begin{tabular}{|l|c|c|c|c|c|}
\hline $\begin{array}{c}\text { Taraf Perlakuan } \\
\text { (Tepung Terigu : } \\
\text { Tepung Bekatul : } \\
\text { Jambu Biji Merah) }\end{array}$ & $\begin{array}{c}\text { Sangat Tidak } \\
\text { Suka }\end{array}$ & Tidak Suka & Suka & $\begin{array}{c}\text { Sangat } \\
\text { Suka }\end{array}$ & Modus \\
\hline $\mathrm{P}_{0}(90: 10: 0)$ & 1 & 8 & 9 & 2 & $3^{\mathrm{a}}$ \\
\hline $\mathrm{P}_{1}(90: 10: 25)$ & 0 & 1 & 13 & 6 & $3^{\mathrm{b}}$ \\
\hline $\mathrm{P}_{2}(90: 10: 30)$ & 0 & 1 & 11 & 8 & $3^{\mathrm{b}}$ \\
\hline $\mathrm{P}_{3}(90: 10: 35)$ & 4 & 5 & 10 & 1 & $3^{\mathrm{a}}$ \\
\hline
\end{tabular}

Keterangan : Huruf yang berbeda menunjukkan adanya perbedaan yang signifikan $(\alpha=0,05)$

Tingkat kesukaan panelis terhadap aroma mie basah cenderung fluktuatif, namun pada perlakuan $\mathrm{P}_{3}$ tingkat kesukaaan panelis cenderung menurun dengan penambahan jambu biji merah. Penurunan tingkat penerimaan panelis terhadap aroma mie basah dipengaruhi oleh bahan penyusunnya yaitu tepung bekatul dan penambahan jambu biji merah. Semakin tinggi proporsi jambu biji merah, aroma mie basah akan semakin langu sehingga tingkat penerimaan panelis cenderung menurun.

Tepung bekatul dan jambu biji merah memiliki aroma yang khas yaitu langu. Hal ini disebabkan karena bekatul mengandung lemak yang cukup tinggi yaitu $16,9 \%$ dan terdapat tokoferol (vitamin E) yang larut dalam minyak. Menurut Dewi,dkk (2011) adanya aroma khas bekatul disebabkan oleh adanya minyak tokoferol (komponen volatil) pada bekatul, sehingga menyebabkan bau khas pada bekatul muncul, sedangkan menurut Soedarya (2010) aroma jambu biji memiliki aroma yang khas dikarenakan adanya senyawa eugenol. Hal ini lah yang menyebabkan aroma jambu biji merah yang semakin mencolok ketika penambahan jambu biji merah dari setiap perlakuan.

Berdasarkan hasil analisis statistik Kruskal Wallis menunjukkan bahwa penambahan jambu biji merah memberikan pengaruh yang signifikan ( $\mathrm{p}$ $=0,000)$ terhadap aroma mie basah. Selanjutnya dilakukan Uji lanjut ManWhitney untuk mengetahui pasangan mana yang berbeda. Dari hasil tersebut menunjukkan bahwa pasangan semua taraf perlakuan memberikan pengaruh yang signifikan kecuali antara $\mathrm{P}_{0}$ dengan $\mathrm{P}_{3}$ dan $\mathrm{P}_{1}$ dengan $\mathrm{P}_{2}$. 


\section{Rasa}

Tabel 5. Tingkat Kesukaan Panelis terhadap Rasa Mie Basah

\begin{tabular}{|l|c|c|c|c|c|}
\hline $\begin{array}{c}\text { Taraf Perlakuan } \\
\text { (Tepung Terigu : } \\
\begin{array}{c}\text { Tepung Bekatul : Jambu } \\
\text { Biji Merah) }\end{array}\end{array}$ & $\begin{array}{c}\text { Jumlah Panelis } \\
\text { Sidak Suka }\end{array}$ & $\begin{array}{c}\text { Tidak } \\
\text { Suka }\end{array}$ & Suka & $\begin{array}{c}\text { Sangat } \\
\text { Suka }\end{array}$ & \multirow{2}{*}{ Modus } \\
\hline $\mathrm{P}_{0}(90: 10: 0)$ & 0 & 3 & 12 & 5 & $3^{\mathrm{a}}$ \\
\hline $\mathrm{P}_{1}(90: 10: 25)$ & 0 & 4 & 12 & 4 & $3^{\mathrm{a}}$ \\
\hline $\mathrm{P}_{2}(90: 10: 30)$ & 0 & 9 & 7 & 4 & $2^{\mathrm{a}}$ \\
\hline $\mathrm{P}_{3}(90: 10: 35)$ & 4 & 7 & 9 & 0 & $3^{\mathrm{b}}$ \\
\hline
\end{tabular}

$(\alpha=0,05)$

Keterangan : Huruf yang berbeda menunjukkan adanya perbedaan yang signifikan

\section{Berdasarkan Tabel 5 diatas $\quad$ Berdasarkan hasil analisis statistik} menunjukkan bahwa tingkat kesukaan Kruskal Wallis dengan tingkat kepercayaan panelis terhadap rasa mie basah cenderung 95\% menunjukkan bahwa penambahan menurun dengan penambahan jambu biji jambu biji merah memberikan pengaruh merah. Penurunan tingkat penerimaan yang signifikan $(\mathrm{p}=0,006)$ terhadap rasa panelis terhadap rasa mie basah dipengaruhi mie basah. Selanjutnya dilakukan Uji oleh bahan penyusunnya yaitu jambu biji lanjut Man-Whitney. Hasilnya adalah merah. Semakin tinggi penambahan perlakuan yang memberikan pengaruh proporsi jambu biji merah akan signifikan terhadap rasa mie basah adalah menimbulkan after taste yaitu sepat. Hal $\mathrm{P}_{0}$ dengan $\mathrm{P}_{3}$ dan $\mathrm{P}_{1}$ dengan $\mathrm{P}_{3}$. ini dikarenakan jambu biji merah yang mengandung tanin (Rukmana, 1996).

\section{Tekstur}

Tabel 6. Tingkat Kesukaan Panelis terhadap Tekstur Mie Basah

\begin{tabular}{|l|c|c|c|c|c|}
\hline $\begin{array}{c}\text { Taraf Perlakuan } \\
\text { (Tepung Terigu : }\end{array}$ & \multicolumn{4}{|c|}{ Jumlah Panelis } & \multirow{2}{*}{ Modus } \\
\cline { 2 - 5 } $\begin{array}{c}\text { Tepung Bekatul : } \\
\text { Jambu Biji Merah) }\end{array}$ & $\begin{array}{c}\text { Sangat } \\
\text { Tidak Suka }\end{array}$ & $\begin{array}{c}\text { Tidak } \\
\text { Suka }\end{array}$ & Suka & $\begin{array}{c}\text { Sangat } \\
\text { Suka }\end{array}$ & \\
\hline $\mathrm{P}_{0}(90: 10: 0)$ & 0 & 2 & 11 & 7 & $3^{\mathrm{a}}$ \\
\hline $\mathrm{P}_{1}(90: 10: 25)$ & 0 & 4 & 12 & 4 & $3^{\mathrm{a}}$ \\
\hline $\mathrm{P}_{2}(90: 10: 30)$ & 1 & 5 & 11 & 3 & $3^{\mathrm{a}}$ \\
\hline $\mathrm{P}_{3}(90: 10: 35)$ & 0 & 11 & 8 & 1 & $2^{\mathrm{b}}$ \\
\hline
\end{tabular}

Keterangan : Huruf yang berbeda menunjukkan adanya perbedaan yang signifikan $(\alpha=0,05)$ 
Tingkat kesukaan panelis terhadap tekstur mie basah cenderung menurun dengan penambahan jambu biji merah. Hal ini dapat dilihat pada Tabel 6 diatas. Semakin tinggi proporsi penambahan jambu biji merah akan mempengaruhi tekstur mie basah, karena bekatul dan jambu biji memiliki kadar serat yang tinggi sehingga tingkat elastisitas dan daya putus mie juga berpengaruh. Anonim (2006) menjelaskan bahwa substitusi atau campuran tepung atau bahan lain pada produk mie yang semakin tinggi menyebabkan mie akan mudah patah karena kandungan gluten menurun. Tepung terigu yang memiliki kadar protein tinggi dapat mempengaruhi sifat kenyal pada mie yang dihasilkan.

Berdasarkan hasil analisis uji statistik Kruskal Wallis dengan tingkat kepercayaan 95\% menunjukkan bahwa penambahan jambu biji merah memberikan pengaruh yang signifikan $\quad(p=0,006)$ terhadap tekstur mie basah. Selanjutnya dilakukan Uji lanjut Man-Whitney, perlakuan yang memberikan pengaruh signifikan terhadap tekstur mie basah adalah antara $\mathrm{P}_{0}$ dengan $\mathrm{P}_{3}$ dan $\mathrm{P}_{1}$ dengan $\mathrm{P}_{3}$.

\section{Perlakuan Terbaik}

Perlakuan terbaik dianalisis menggunakan indeks efektivitas, yaitu taraf perlakuan $\mathrm{P}_{1}(90: 10: 25)$. Kandungan gizi: energi 289 kalori, karbohidrat 43,16\%, protein $9,56 \%$, lemak $8,77 \%$, kadar serat $4,18 \%$, dan daya putus $1,67 \mathrm{~N}$.

Mie basah dengan penambahan jambu biji merah pada taraf perlakuan terbaik $\left(\mathrm{P}_{1}\right)$ berdasarkan karateristik nilai energi, mutu kimia, mutu fisik dan mutu organoleptik mie basah disajikan pada Tabel 7.

Tabel 7. Kateristik Mie Basah Bekatul Penambahan Jambu Biji Merah pada Taraf Perlakuan $\mathrm{P}_{1}$ dengan SNI 01-2897-1992 (Mie Basah)

\begin{tabular}{|l|c|c|}
\hline \multicolumn{1}{|c|}{ Karateristik } & Jumlah/100 gram & SNI 01-2897-1992 \\
\hline Energi (kalori) & 289,88 & - \\
\hline Karbohidrat (\%) & 43,16 & - \\
\hline Protein (\%) & 9,56 & Min. 8 \\
\hline Lemak (\%) & 8,77 & - \\
\hline Kadar serat (\%) & 4,18 & - \\
\hline Kadar air (\%) & 37,01 & $20-35$ \\
\hline Kadar abu (\%) & 1,48 & Maks 3 \\
\hline Elastisitas (\%) & 20 & - \\
\hline Daya putus (N) & 1,67 & - \\
\hline
\end{tabular}




\begin{tabular}{|l|c|c|}
\hline Warna & Kuning kemerahan & Normal \\
\hline Aroma & Agak langu & Normal \\
\hline Rasa & Agak sepat & Normal \\
\hline Tekstur & Agak kasar & Normal \\
\hline
\end{tabular}

\section{KESIMPULAN}

Mutu organoleptik mie basah dengan penambahan jambu biji merah meliputi warna, aroma, rasa dan tekstur disukai panelis, namun tingkat kesukaan aroma, rasa dan tekstur menurun sejalan dengan peningkatan jambu biji merah, kecuali pada warna, tingkat kesukaan panelis meningkat. Formulasi mie basah dengan penambahan jambu biji merah pada setiap perlakuan

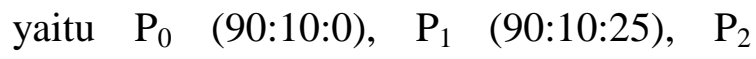
(90:10:30) dan $\mathrm{P}_{3}$ (90:10:35) berpengaruh signifikan terhadap mutu organoleptik mie basah bekatul. Taraf perlakuan terbaik pada mie basah bekatul adalah $\mathrm{P}_{1}(90: 10: 25)$, dengan kandungan gizi: energi 289 kalori, karbohidrat 43,16\%, protein 9,56\%, lemak $8,77 \%$, kadar serat $4,18 \%$, dan daya putus $1,67 \mathrm{~N}$ serta elastisitas $20 \%$.

\section{SARAN}

Saran untuk penelitian ini adalah perlu penambahan bahan tambahan pangan (BTP) untuk memperbaiki tekstur mie basah agar lebih kenyal dan tidak mudah putus, misal STPP (sodium tri polyphospat) yang berfungsi sebagai pengemulsi sehingga dihasilkan adonan yang lebih homogen (rata), menurut SNI penambahan sekitar $0,3 \%$. Selain itu tekstur mie terasa berpasir sehingga sebaiknya biji jambu merah tidak digunakan.

\section{DAFTAR PUSTAKA}

Anonim, (2006). Teknologi Mie Instan. http://www.ebookpangan.com Diakses tanggal 27 Juni 2016.

Depkes RI. (2005). Daftar Komposisi Bahan Makanan. Politeknik Kesehatan Kemenkes Malang

Dewi, N .M.A.P, dkk. (2011). Stabilisasi Bekatul dalam Upaya Pemanfaatannya Sebagai Pangan Fungsional. Jurnal kesehatan vol. 15 No.1, Juni 2011: 37-43 http://download.portalgaruda.org/ article.php?article. Diakses tanggal 14 Januaril 2016]

Fitriyaningsih, E., Miko,A. dan Suryana. (2011). Pemanfaatan Tepung Bekatul Terhadap Daya Terima Mie Basah. Jurusan Gizi Poltekkes Aceh.

Parimin, S.P. (2007), Jambu Biji Budidaya dan Ragam Pengolahannya, ebook, https://books.google.co.id/books?id=yBTe p1IW3swC\&pg=PP6\&lpg $=P P 6 \& d q=j a m b$ u+biji+budidaya+dan+ragam+pemanfaata nnya. Tanggal akses 21 Desember 2015.

Riset Kesehatan Dasar (Riskesdas) (2013). (http://repository.unhas.ac.id/bitstream/han dle/123456789/11500/BAB\%201\%20S3 Kadek.pdf?sequence $=3$. Diakses Tanggal 5 Desember 2015. 
Rukmana, R.(1996). Jambu Biji. Yogyakarta: Kanisius

Rustandi, Deddy. (2011). Produksi Mie. Solo. PT Tiga Serangkai Pustaka Mandiri.

Soedarya, A. P. (2010). Agribisnis Guava (Jambu Biji). Pustaka Grafika. Bandung. 